\title{
Unison with Oneself in God at the Sacred «Kamppi Chapel of Silence»
}

\author{
Encontrarse con uno mismo y con Dios en la «Kamppi Chapel of Silence»
}

Hee Sook Lee-Niinioja · Oxford Brookes University (Reino Unido)

https://doi.org/10.17979/aarc.2013.3.0.5107

\section{RESUMEN}

En 2012, como parte del programa World Design Capital, se inauguró en Helsinki la Kamppi Chapel of Silence, con el fin de proporcional a los ciudadanos un momento de silencio, relax y encuentro en el área más concurrida de la ciudad: la entrada del centro comercial Kamppi. A partir de estos hechos nos podríamos preguntar: ¿Cual era el objetivo real de todo esto? ¿El resultado de los deseos ciudadanos de estar con Dios, sin ser molestados por los turistas? ¿Tal vez una estrategia para atraer a más cristianos en una sociedad multirreligiosa? ¿Una nueva modalidad de caridad luterana al servicio de las necesidades de la gente? Mi comunicación analiza las relaciones entre las formas arquitectónicas y las emociones en los espacios sagrados, a través de varias iglesias finlandesas históricas.

\begin{abstract}
In 2012, as part of World Design Capital program, Kamppi Chapel of Silence was inaugurated at the entrance of Kamppi shopping centre in Helsinki, providing a place for citizen's moment of silence, relax and meeting in the busiest area. These facts raise questions: What was the real aim behind this? Is this the result of citizens' wishes to be with God, undisturbed by tourists? A strategy for attracting more Christians in multi-religious society? A new way of Lutheran charity in service to needy people? My paper analyses relationship between architectural forms and emotions in sacred spaces through historical Finnish churches.
\end{abstract}

\section{PALABRAS CLAVE}

Kamppi Capilla del Silencio Helsinki; Iglesia finlandesa; edificio sacro; arquitectura contemporánea; formas emotivas.

\section{KEYWORDS}

Kamppi Chapel of Silence Helsinki; Finnish Church; Sacred Building; Contemporary Architecture; Emotional Forms. 


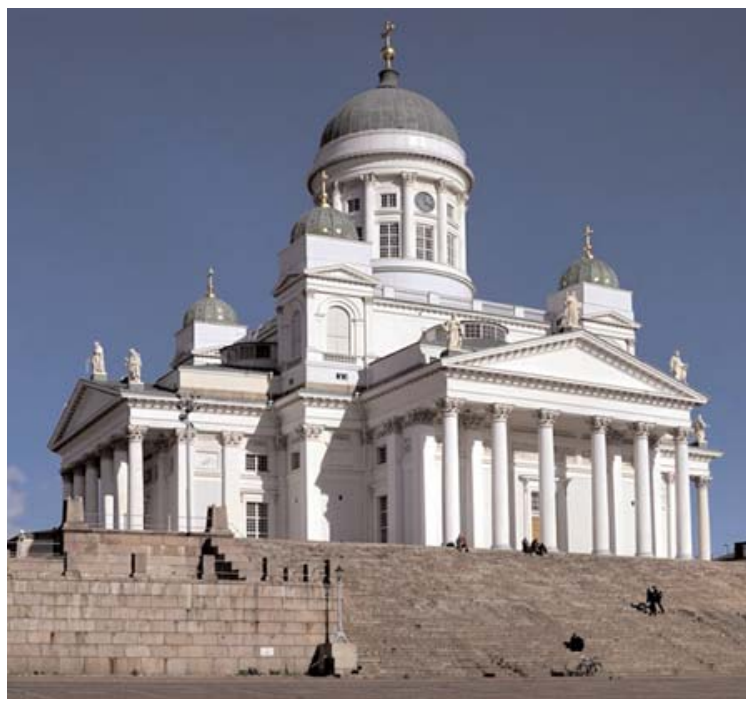

\section{THE FINNISH CHURCH}

During the Viking period (IX-XI centuries), the earliest Christian influences arrived in Finland from the Greek Byzantine culture through the eastern Viking route and by the trade routes of Novgorod stretching to western Finland. The tradition says that the influence was an outcome of a crusade led by St. Eric in the mid 12th century.

And the English missionary Henry, bishop of Uppsala (Sweden), who started organising the Church, but killed by the peasant Lalli, is believed both the first bishop of Finland and the country's national saint after his martyrdom.

The founding of the Cathedral Chapter of Turku is dated to 1276, and relations with the Pope in Rome and Avignon were regular, shown in Finnish believers' international pilgrimages. The earliest churches were probably built of wood, but surviving buildings are of grey granite, mostly from the 15th century.

Church of Finland changed from the Roman Catholic to the Lutheran faith during the Protestant Reformation. Reformation started in Finland with the central role of Michael Agricola. Evangelical faith was established by the mid 16th century, so that the Finnish Church was characterised by a Lutheran orthodoxy by Sweden as victor of Protestantism in the Thirty Years War (1618/48). The ruler was head of the Church, and
Fig. 01. Carl Ludwig Engel, St. Nicholas Cathedral, Helsinki, 1830/53.

his position was supported by theocratic arguments. All citizens should be its member.

To revitalise spiritual life, German Halle moderate pietism reached Finland at the turn of the 18th century, and the Church reformed its organisation and developed new modes of activity in the next century. However, after Finland's independence (1917), the Civil War estranged the Church and the workers' movement, and Freedom of Worship Act (1923) came into force.

Of two state churches (Lutheran/Orthodox), the Evangelical Lutheran Church of Finland is primary. Since World War II, secularisation took a strong hold, and demarcation was laid between the sacred and the profane. Values based on religion have lost status in society, replaced by new sets of values and morals, linking feebly with the church.

\section{HELSINKI CATHEDRAL AND TEMPPELIAUKIO $\mathrm{CHURCH}$}

Helsinki, the capital, was formed by religious influences from both the East and West, and several architectural layers appeared over 450 years. Nature blends with high-tech achievements, while traditions with the contemporary trends in the city. For example, Helsinki Cathedral (Fig. 01), built in 1830/53, was a tribute to Tsar Nicholas I of Russia, attracting numerous tourists with its tall, green dome in the neoclassical 


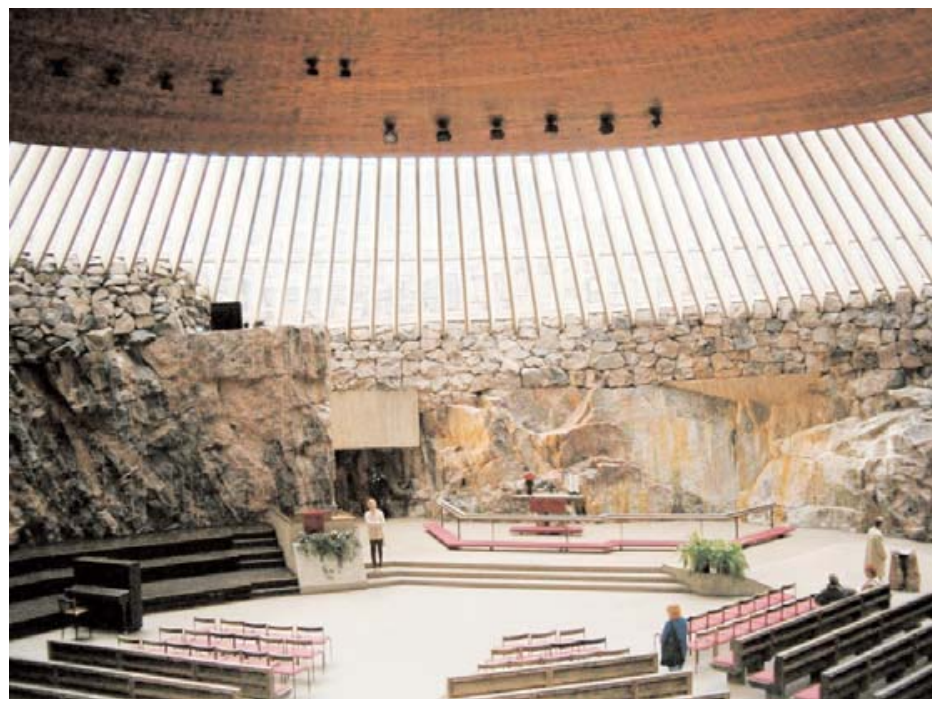

Fig. 02. Timo and Tuomo Suomalainen, Temppeliaukio Church, Helsinki, 1969.

style, while Temppeliaukio Church (Fig. 02), completed in 1969 with a popular name — Rock Church — is a must for tourists as well, due to its solid construction. Natural light brightens the inside through 180 glasses between the dome and the walls.

To begin with, known as St. Nicholas' church until the Independence, Helsinki Cathedral is the Lutheran church in the city's center. A neoclassic style of a tall and green dome is surrounded by four smaller domes, designed by Carl Ludwig Engel as the peak of his Senate Square layout. The church's plan is a Greek cross symmetrical in each of the four cardinal directions, with each arm's façade featuring a colonnade and pediment. The cathedral was built on the site of a smaller Ulrika Eleonora Church, dedicated to its patroness, Ulrika Eleonora, Queen of Sweden. The building was later altered by Ernst Lohrmann, who took the model of Saint Isaac's Cathedral in St. Petersburg.

On the other hand, Temppeliaukio Church was built in 1969 by the architect brothers, Timo and Tuomo Suomalainen. Excavated into solid rock, the church is situated in the heart of Helsinki. Its hall is covered with a dome, lined with copper and supported on the rock walls by reinforced concrete beams. The interior walls have rugged rock, reflecting the sunlight through roof windows. The diameter of the dome is $24 \mathrm{~m}$.; the walls are 5-9 $\mathrm{m}$. high.
Serving as important architectural sights to any visitors, the two churches can evoke emotional experience as sublime and spiritual.

\section{KAMPPI CHAPEL OF SILENCE}

Kamppi Chapel of Silence is located in a corner of the Narinkkatori square in Helsinki, at the entrance of the Kamppi shopping center. The Chapel is intended to be a space where people can spend a time of silence and meet each other. It offers an opportunity to calm down in the middle of one of the busiest areas in Finland (Fig. 03-06).

The Chapel is run on a partnership, by the Helsinki parishes and the Social Services Department of the Helsinki city. Parish and social services, even parish unions of Espoo and Vantaa neighbourhoods are in attendance for personal consultations, and various forms of voluntary work are under progress.

The Chapel was designed by architects Kimmo Lintula, Niko Sirola and Mikko Summanen of K2S Architects Ltd. It is a sample of innovative wood architecture, acquiring much attention before its completion across the globe. It was granted the International Architecture Award 2010 for the Best New Global Design by The Chicago Athenaeum.

With the total floor area of $352 \mathrm{~m} 2$, the most impressive space is the main hall with its height of 11,5 

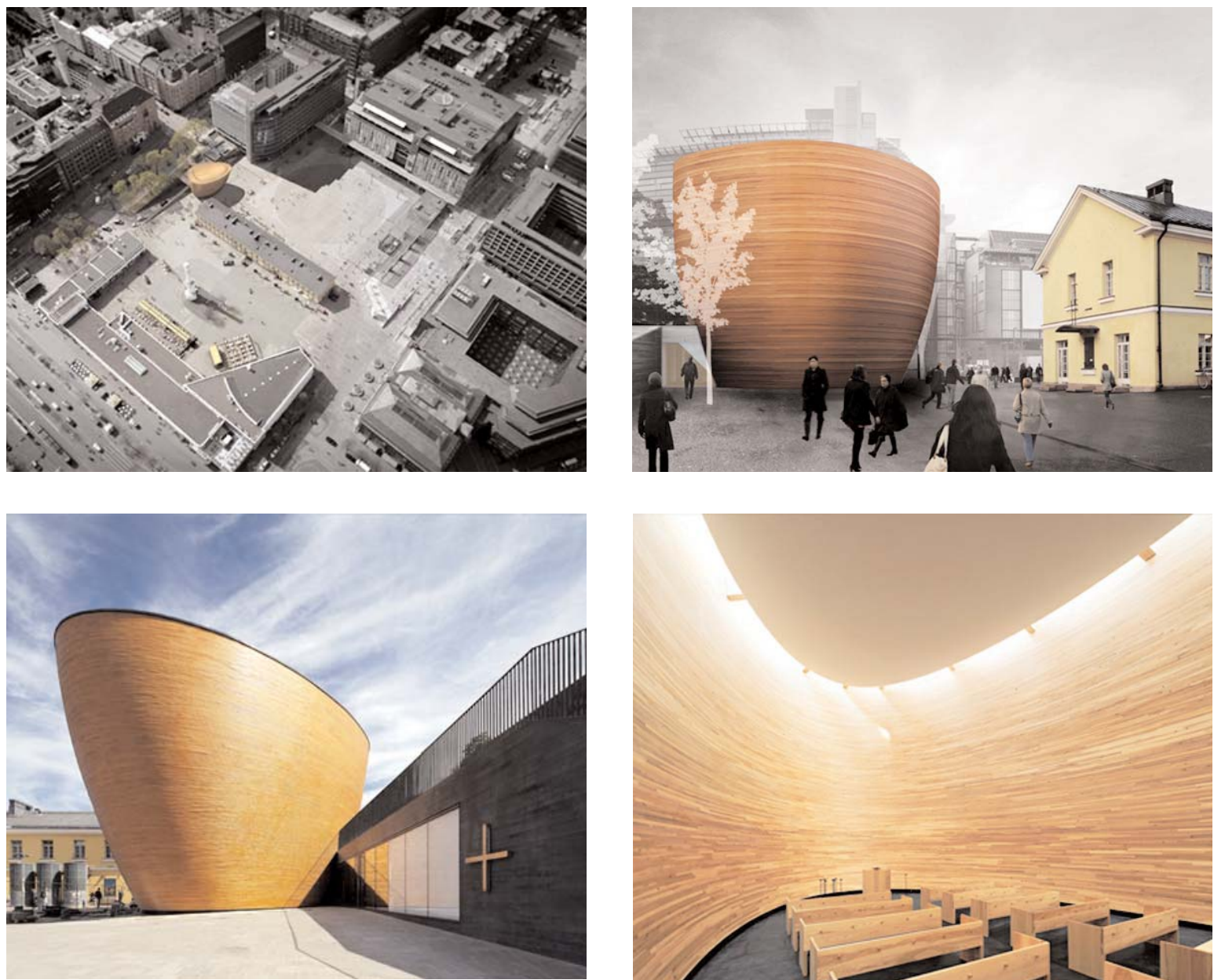

Fig. 03-06. K2S architects, Kamppi Chapel of Silence, Helsinki, 2008/12.

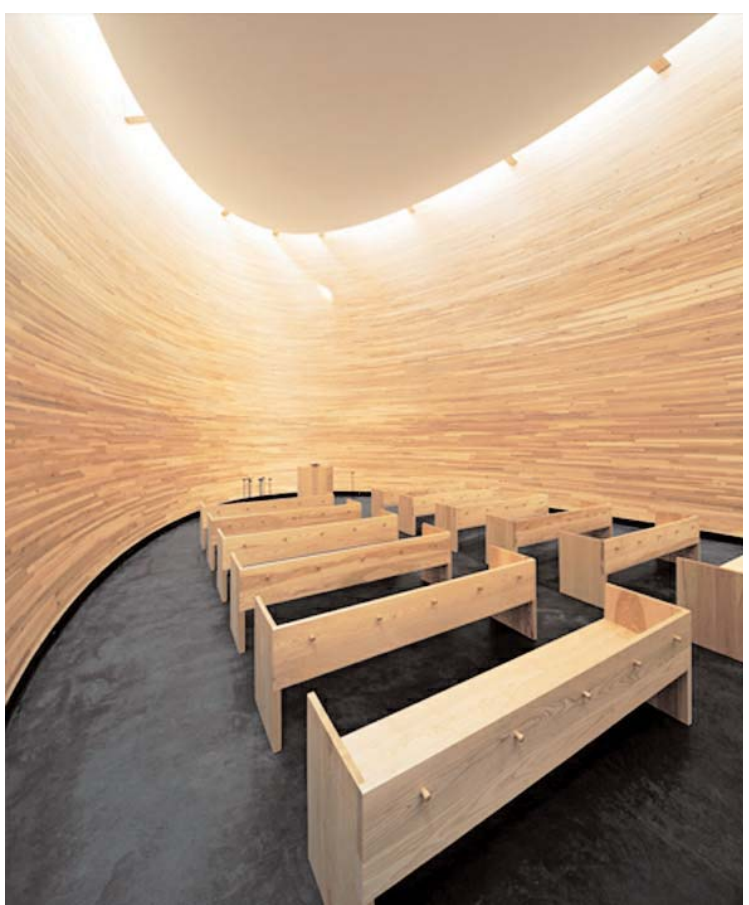


$\mathrm{m}$. In the tranquil area, the hectic environs are blocked out. The light coming indirectly from the ceiling and the warm materials let visitors feel cosy with a kind of sacred ambience. The inner walls of the chapel area are lined with ordinary alder planks cut to shape. The simple and straightforward furnishing of the hall is made of massive ash tree, and the facades are constructed of horizontal spruce strips, bent at different radiuses. The wood is glazed with a special wax.

The curved shape and a robust form of the small chapel building allow the space and views to flow in the urban surroundings, while the soft shape and harmonious form of the interior of the Chapel embraces the visitor in its safety simultaneously. Approachable from every direction, its innovative wooden architecture testifies the famous Finnish design.

\section{EMOTIONAL FORMS IN SACRED BUILDINGS}

My paper intends to discuss of the relationship between architectural forms and emotions in sacred spaces of Finland. In order to do so, some theories on emotions and forms are needed.

According to Daniel Goleman (1995), emotion is a neural impulse due to its psycho-physiological state which moves an organism to action. Emotions may be characterized from their affective phenomena - moods and personality traits - by temporal duration. The role of emotions has been discussed with three traditions since the Antiquity in moral behaviour of the Western thought.

First, Plato (c.428-348 BC) and Immanuel Kant thought emotions as hindering to good behaviour. Plato compared the rational mind to a charioteer whose duty was to keep his horses. For Kant (1785), good actions were only truly moral without motivation by any emotion.

Second, Aristotle (384-322 BC) and economist Adam Smith (1759) regarded emotions as crucial ingredients in generating moral conduct. Aristotle claimed that certain social emotions - sympathy - lay at the heart of all ethical behaviour.

Third, all moral judgements are an expression of the speaker's emotions. David Hume (1751) says that a certain action is said to be right or wrong, and the speaker has a feeling of approval or disapproval to the action.

However, the philosophy of emotions has recently addressed other questions. Paul Griffiths (1997) argues that emotions are an assorted cluster of phenomena which cannot comprise a single natural kind.

Regarding form, it is a perfect combination of all visual elements, themes, moods, techniques, functions, structure, and organization, taking many characteristics of a recognizable appearance or a particular condition in which something manifests itself. In design, it is the shape of three-dimensional volume defined by the lines of its borders. Forms can be divided into natural and geometric forms. And its difference is that natural forms are representational; geometric forms not.

In a theory of the 20th century, five basic geometric forms are sphere, cube, cylinder, cone and pyramid. As primary forms, their parts are related to one another in a consistent and orderly manner: symmetrical, steady in their nature. Non-primary are dissimilar: asymmetrical and more dynamic than primary.

Originated from the Latin word forma, each form bears a primary function and many subsidiary ones. In architecture, it serves to inspire, inform, or move viewers to action. In other words, to inform means clarifying, explaining, and identifying; to enlighten does revealing; to persuade does suggestion. In this regard, there is a direct reciprocal relationship between form and space, as space creates the distance required to perceive form. The more significance the form displays, the more space recedes in our perception and experience.

As the appearance and use of form can influence culture and viewers' perception of it, form needs interpretation. It is the translation of its meaning through the filter of different perspectives based on viewers' experiences and necessity of philosophical ideologies.

Under this process, there arises a caution, because a form can be ambiguous with many interpretations. And ambiguity can be accompanied by contradiction of views in form and function. Nevertheless, ambiguity and contradiction should be accepted in the design of a work and in its interpretation, because the form can play as a means of communication in diverse cultural environments beyond time and space.

In short, form in architecture is related both to space and a vehicle for meaning. Where meaning is deleted by the architect, form has an effect on people in a different way. 


\section{CONCLUSION}

Returning to Helsinki churches, their forms recall the Renaissance theoretician Leon Battista Alberti (1404/72), who proposed that the ornamentation on buildings convey feelings of majesty, authority, and dignity. By moving the passion of the spectator through their architectural splendour, buildings persuade the viewer to feel the majesty of God or the dignity of the State. Moreover, John Ruskin in his Stones of Venice (1855) underlined that buildings should respect the culture from which they have developed.

If these arguments can be specifically applied to Kamppi Chapel Silence, its exquisite form without ornamentation calls our emotions with different interpretations, yet linking to God. We feel unison with ourselves in God at the sacred space, and this may cause a new attraction to ever-increasing tourists in Helsinki. Perhaps, it was God's intention to let them return to Him?

\section{PROCEDENCE OF ILUSTRATIONS}

Fig. 01-02. Wikimedia Commons.

Fig. 03-06. K2S architects.

\section{REFERENCES}

Adam Smith, The Theory of Moral Sentiments (London: A. Millar, 1759).

Daniel Goleman, Emotional Intelligence (New York: Bantam Books, 1995).

David Hume, An Enquiry Concerning The Principles of Morals (London: A. Millar, 1751).

Francis D.K. Ching, Architecture, Form, Space and Order (New York/London: Van Nostrand Reinhold, 1996).

Howard Robertson, The Principles of Architectural Composition (London: The Architectural Press, 1955).

John Ruskin, The Stones of Venice (New York: Da Capo, 1985).

Jürgen Joedicke, Space and Form in Architecture (Stuttgart: Karl Krämer Verlag, 1985)

P.E. Griffiths, What Emotions Really Are: The Problem of Psychological Categories (Chicago: University of Chicago Press, 1997).

Paul Jacques Grillo, Form, Function and Design (New York: Dover Publications, Inc., 1960).

Robert Tavernor, On Alberti and The Art of Building (New Haven: Yale University Press, 1998).

Rudolf Arnheim, Art and Visual Perception: A Psychology of The Creative Eye (Berkeley: Univ. of California Press, 1974). 